\title{
Effect of rejuvenation pruning on the growth, productivity and disease incidence in declining trees of pomegranate (Punica granatum L.) cv. Kandhari Kabuli
}

\author{
D. P. Sharma and Niranjan Singh* \\ Department of Fruit Science, College of Horticulture, Dr. YS Parmar University of Horticulture and Forestry, \\ Nauni, Solan-173230 (HP), INDIA \\ *Corresponding author. E-mail: niranjangautam@gmail.com
}

Received: Janaury 25, 2016; Revised received: November 23, 2017; Accepted: February 10, 2018

\begin{abstract}
Pruning of fruit trees is an important aspect for the improvement of fruit quality and to minimize the pests and disease attack. Pruning was performed in the month of December in seven year old unpruned trees of Punica granatum cv. Knadhdri Kabuli having many interfering branching and a heavy infestation of bacterial blight orchard. The pruning treatments viz., $T_{1}$ : Retention of $15 \mathrm{~cm}$ fruiting shoot length, $T_{2}$ : Retention of $30 \mathrm{~cm}$ fruiting shoot length, $T_{3}$ : Retention of $45 \mathrm{~cm}$ fruiting shoot length, $T_{4}$ : Retention of $60 \mathrm{~cm}$ fruiting shoot length and $T_{5}$ : control (No heading back and no thinning) plant. The results of the present investigation revealed that among different pruning treatment, the best results in terms of shoot extension $(56.34 \mathrm{~cm}$ ), fruit size (Diameter $9.66 \mathrm{~cm}$ and Length $9.65 \mathrm{~cm}$, fruit weight $(278.50 \mathrm{~g})$, marketable yield $(10.25 \mathrm{~kg})$ and fruit qualities were in fruits from $T_{1}$ and $T_{2}$ where retention of $15 \mathrm{~cm}$ fruiting shoot length respectively and retention of $30 \mathrm{~cm}$ fruiting shoot length were maintained. However, maximum fruit set $(54.73 \%)$ was recorded in control, and it decreased with increasing pruning intensity. The pruning treatments also proved beneficial in controlling bacterial blight on fruit $(12.86 \%)$ and leaf surface $(26.60 \%)$ to some extent.
\end{abstract}

Keywords: Disease incidence, Fruit quality, Pomegranate, Pruning, Yield

\section{INTRODUCTION}

Pomegranate (Punica granatum L.) is one of the ancient and highly praised favorite fruit of Mediterranean, tropical and subtropical regions of the world. India is the world's leading producer of pomegranate with nearly $50 \%$ of world's production. The total area under this fruit at present accounted for 131 thousand hectares with an annual production of 1346 thousand metric tons and productivity of $10.3 \mathrm{MT} / \mathrm{ha}$ in India. In Himachal Pradesh, the total area under this fruit accounted for 2.20 thousand hectares with an annual production of 2.54 thousand metric ton (Anonymous, 2015). However, productivity of Himachal Pradesh is $0.44 \mathrm{MT} / \mathrm{ha}$, which is quite low compared to the national productivity of $10.3 \mathrm{MT} / \mathrm{ha}$. It is important commercial fruit preferred by the consumer all over the world for its sweet- acidic taste, fine dessert quality and excellent blend. The fruit is also popular due to the organoleptic characteristics of the arils (i.e. the seeds), nutritional and therapeutic values for its usefulness in cancer, indigestion and leprosy cure. Pomegranate is widely considered native in the region from Iran to Northern India (Chandra et al., 2010). The fruit is commercially cultivated in Mediterranean region and in countries like Spain, Morocco, Egypt, Pakistan
(Baluchistan), Afghanistan, Iraq, Iran, China, Japan, Russia and India. Of late, this crop is gaining popularity in arid and semiarid regions of India due to its wide adaptability, higher yield, drought hardiness and tolerance to salinity. In terms of farmer's economy, pomegranate is next to grape in its importance and is being in various districts of Maharashtra, commercially (Kaulgud, 2002). Pomegranate has a deep association with the culture of Mediterranean region and Near East where it is a savoured delicacy and is an important dietary component and greatly appreciated for its medicinal properties (Stover and Mecure, 2007). Currently, there is a greater interest in pomegranate juice due to its anti-oxidant activities and potential health benefits (Hess and Kadar, 2003). The anthocyanins of pomegranate have rich anti-oxidant property. The anthocyanin responsible for pigmentation of the pomegranate was isolated and identified as 3, 5-diglucoside delphindin (DP-2, 5) and 3, glucoside (DP-3), cynadin 3, 5-diglucoside (Cy-3, 5) and 3-glucoside (CY-3), peralgonidin 3, 5-diglucoside (Pg-3, 5) and 3-glucoside (Pg3) (Du et al., 1975).

Pruning is the most important practices for successful and sustainable cultivation of the fruit crop including pomegranate. Pruning improves light penetration and air circulation, which results in better fruit quality and 
also in minimize the pests allele and disease spread (Sharma and Chauhan, 2004). Orchard floor management practices help in also a better light interception, regulation of soil erosion, reduced surface run-off and suppress weed population (Warade et al., 2008). The studies were conducted with to the improve growth, fruiting, fruit quality, yield and disease incidence of bacterial blight quality in declining Punica granatum trees.

\section{MATERIALS AND METHODS}

The present investigation was carried out in the experimental orchard of Department of Fruit Science, Dr. Yashwant Singh Parmar University of Horticulture and Forestry, Solan, Nauni, (H.P.) under rain fed mid hill conditions during the year 2012 and 2013. The soil is mountainous alluvial loamy soil and having $\mathrm{pH}$ 6.62, organic carbon $1.58 \%$, available $\mathrm{N}, \mathrm{P}$ and $\mathrm{K}$ were $318.64,16.62$ and $172 \mathrm{~kg} / \mathrm{ha}$, respectively. Five pruning treatment intensities viz., $\mathrm{T}_{1}$ : Retention of $15 \mathrm{~cm}$ fruiting shoot length + Thinning, $\mathrm{T}_{2}$ : Retention of $30 \mathrm{~cm}$ fruiting shoot length + Thinning, $\mathrm{T}_{3}$ : Retention of $45 \mathrm{~cm}$ fruiting shoot length + Thinning, $\mathrm{T}_{4}$ : Retention of $60 \mathrm{~cm}$ fruiting shoot length + Thinning and $\mathrm{T}_{5}$ : Control (No head-back + no thinning), were exercised in Randomized Block Design with three replications on uniformly 7- years old unpruned declining ' Kandari Kabuli-' pomegranate trees. The orchard is located on the North Eastern side of the hilly tract under the sub temperate, sub-humid mid-hill agro climatic zone II of Himachal Pradesh, situated at an elevation of $1250 \mathrm{~m}$ above mean sea level at the $30^{\circ} 51$ 'N latitude and $76^{\circ} 11^{\prime} \mathrm{E}$ longitude. The pruning was carried out on the trees in dormant season during both the years of study, i.e., 2012 and 2013. Rejuvenation pruning was done on selected trees in dormant season during the first week of February 2012 while in January 2013 only the corrective pruning was uniformly carried out in all the pruned trees. Observations regarding growth parameters, viz. annual shoot growth, trunk girth, tree spread, tree volume, pruning weight, leaf area and chlorophyll content were recorded according to standard procedures during both the years of study. The fruits were harvested carefully at full maturity and brought to the laboratory for analysis. After harvest fruit yield, fruit size, weight, fruit volume and fruit firmness were recorded with the standard procedure (AOAC, 1980) to determine physical properties of fruits. The fruits were also analyzed for chemical Gomez constituents, i.e., total soluble solids (TSS), titratable acidity and sugars (total, reducing and nonreducing). TSS was determined by hand refractometer at room temperature and was expressed in terms of degree $\left({ }^{\circ} \mathrm{B}\right)$. The prevalence of the diseases; the incidence and severity of disease were recorded in the pomegranate growing fruits and leaves treatment plants. The fruits and plants were in order to record the prevalence of the diseases; the incidence and severity were recorded in the pomegranate growing areas in different localities surveyed. The data generated from these investigations were appropriately computed, tabulated and analysed in accordance with procedures outlined by (Gomez and Gomez, 1984).

\section{RESULTS AND DISCUSSION}

Plant vigour: Among all the treatments under study, $\mathrm{T}_{1}$ recorded maximum shoot extension growth with

Table 1. Effect of different levels of rejuvenation pruning on tree growth characters in pomegranate cv. Kandhari Kabuli.

\begin{tabular}{lccccc}
\hline Treatment & $\begin{array}{c}\text { Shoot extension } \\
\text { growth }(\mathbf{c m})\end{array}$ & $\begin{array}{c}\text { Plant } \\
\text { spread }(\mathbf{m})\end{array}$ & $\begin{array}{c}\text { Plant } \\
\text { hheight }(\mathbf{m})\end{array}$ & $\begin{array}{c}\text { Tree } \\
\text { volume }\left(\mathbf{m}^{\mathbf{3}}\right)\end{array}$ & $\begin{array}{c}\text { Fruit } \\
\text { volume }\left(\mathbf{c m}^{\mathbf{3}}\right)\end{array}$ \\
\hline Retention of 15cm fruiting shoot length + Thinning $\left(\mathrm{T}_{1}\right)$ & 56.34 & 1.60 & 1.52 & 1.89 & 270.33 \\
Retention of 30cm fruiting shoot length + Thinning $\left(\mathrm{T}_{2}\right)$ & 52.95 & 1.80 & 1.76 & 4.24 & 260.50 \\
Retention of 45cm fruiting shoot length + Thinning $\left(\mathrm{T}_{3}\right)$ & 45.67 & 2.01 & 2.05 & 5.59 & 240.83 \\
Retention of 60cm fruiting shoot length + Thinning $\left(\mathrm{T}_{4}\right)$ & 41.23 & 2.22 & 2.45 & 6.33 & 233.83 \\
(No head-back + No thinning $\left(\mathrm{T}_{5}\right)$ & 41.34 & 2.60 & 2.70 & 9.31 & 209.83 \\
$\mathrm{CD}_{0.05}$ & 2.45 & 0.35 & 0.25 & 0.76 & 4.06 \\
\hline
\end{tabular}

Table 2. Effect of different levels of rejuvenation pruning on fruiting, yield and physical characters of pomegranate cv. Kandhari Kabuli.

\begin{tabular}{|c|c|c|c|c|c|c|c|c|}
\hline \multirow[b]{2}{*}{ Treatment } & \multirow{2}{*}{$\begin{array}{l}\text { Fruit } \\
\text { set } \\
(\%)\end{array}$} & \multirow{2}{*}{$\begin{array}{l}\text { Fruit } \\
\text { drop (\%) }\end{array}$} & \multirow{2}{*}{$\begin{array}{l}\text { Fruit } \\
\text { crack } \\
(\%)\end{array}$} & \multirow{2}{*}{$\begin{array}{l}\text { No. of } \\
\text { fruits/ } \\
\text { Tree }\end{array}$} & \multicolumn{2}{|c|}{ Fruit size (cm) } & \multirow{2}{*}{$\begin{array}{l}\text { Fruit } \\
\text { weight } \\
\text { (g) }\end{array}$} & \multirow{2}{*}{$\begin{array}{l}\text { Yield } \\
(\mathrm{Kg})\end{array}$} \\
\hline & & & & & Diameter & Length & & \\
\hline $\begin{array}{l}\text { Retention of } 15 \mathrm{~cm} \text { fruiting shoot } \\
\text { length }+ \text { Thinning }\left(T_{1}\right)\end{array}$ & 45.96 & 12.11 & 2.50 & 28.33 & 9.66 & 9.65 & 278.50 & 7.65 \\
\hline $\begin{array}{l}\text { Retention of } 30 \mathrm{~cm} \text { fruiting shoot } \\
\text { length }+ \text { Thinning }\left(\mathrm{T}_{2}\right)\end{array}$ & 48.60 & 14.13 & 2.43 & 29.33 & 9.55 & 9.52 & 263.16 & 7.80 \\
\hline $\begin{array}{l}\text { Retention of } 45 \mathrm{~cm} \text { fruiting shoot } \\
\text { length }+ \text { Thinning }\left(T_{3}\right)\end{array}$ & 52.33 & 15.32 & 2.00 & 34.66 & 9.50 & 9.26 & 241.33 & 8.35 \\
\hline $\begin{array}{l}\text { Retention of } 60 \mathrm{~cm} \text { fruiting shoot } \\
\text { length }+ \text { Thinning }\left(\mathrm{T}_{4}\right)\end{array}$ & 53.22 & 22.42 & 1.70 & 47.00 & 9.39 & 9.39 & 214.00 & 10.05 \\
\hline (No head-back + No thinning $\left(T_{5}\right)$ & 54.73 & 25.34 & 2.20 & 49.00 & 9.29 & 9.13 & 210.50 & 10.25 \\
\hline $\mathrm{CD}_{0.05}$ & 3.12 & 2.54 & 0.31 & 1.39 & 0.08 & 0.05 & 16.90 & 0.17 \\
\hline
\end{tabular}


Table 3. Effect of different levels of rejuvenation pruning fruit physicochemical characters in pomegranate cv. Kandhari Kabuli.

\begin{tabular}{|c|c|c|c|c|c|c|c|}
\hline Treatment & $\begin{array}{l}\text { TSS } \\
\left({ }^{0} \text { Brix }\right)\end{array}$ & $\begin{array}{l}\text { Titratable } \\
\text { Acidity ( \% ) }\end{array}$ & $\begin{array}{l}\text { Total S } \\
\operatorname{ars}(\%)\end{array}$ & $\begin{array}{l}\text { Sug-reducing } \\
\text { ) sugars }(\%\end{array}$ & $\begin{array}{l}\text { Non-reducing } \\
\text { sugars } \quad(\%)\end{array}$ & $\begin{array}{l}\text { Ascorbi } \\
\text { acid }\end{array}$ & $\begin{array}{l}\text { TSS :Aci } \\
\text { d ratio }\end{array}$ \\
\hline $\begin{array}{l}\text { Retention of } 15 \mathrm{~cm} \text { fruiting shoot length }- \\
\text { Thinning }\left(T_{1}\right)\end{array}$ & $+{ }_{13.60}$ & 0.32 & 11.91 & 9.45 & 2.46 & 15.95 & 42.10 \\
\hline $\begin{array}{l}\text { Retention of } 30 \mathrm{~cm} \text { fruiting shoot length } \\
\text { Thinning }\left(T_{2}\right)\end{array}$ & ${ }^{+}{ }_{13.36}$ & 0.40 & 11.71 & 9.37 & 2.34 & 15.75 & 32.84 \\
\hline $\begin{array}{l}\text { Retention of } 45 \mathrm{~cm} \text { fruiting shoot length } \\
\text { Thinning }\left(T_{3}\right)\end{array}$ & ${ }^{+}{ }_{13.13}$ & 0.45 & 11.30 & 9.20 & 2.10 & 15.31 & 28.98 \\
\hline $\begin{array}{l}\text { Retention of } 60 \mathrm{~cm} \text { fruiting shoot length } \\
\text { Thinning }\left(T_{4}\right)\end{array}$ & ${ }^{+}{ }_{13.03}$ & 0.51 & 10.57 & 8.57 & 2.00 & 14.05 & 25.54 \\
\hline (No head-back + No thinning $\left(\mathrm{T}_{5}\right)$ & 12.40 & 0.56 & 9.89 & 8.43 & 1.46 & 12.85 & 21.86 \\
\hline $\mathrm{CD}_{0.05}$ & 0.32 & 0.01 & 0.10 & 0.09 & 0.08 & 0.32 & 1.24 \\
\hline
\end{tabular}

Table 4. Effect of different levels of rejuvenation pruning disease incidence on fruit and leaf surface in pomegranate cv. Kandhari Kabuli.

\begin{tabular}{|c|c|c|c|c|c|c|c|c|c|}
\hline \multirow{2}{*}{ Treatment } & \multicolumn{2}{|c|}{$\begin{array}{l}\begin{array}{l}\text { Disease } \\
\text { fruit surface }\end{array} \\
\end{array}$} & \multicolumn{2}{|c|}{ severity } & on & $\begin{array}{l}\text { Disease } \\
\text { leaf surface }\end{array}$ & severity & $\%$ & on \\
\hline & $\begin{array}{l}B_{1} \\
\text { days ( } \%\end{array}$ & $\begin{array}{ll}15 \\
0)\end{array}$ & $\begin{array}{lr}B_{2} & 30 \\
\text { days } & (\%) \\
\end{array}$ & 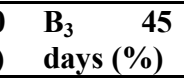 & Mean & $\begin{array}{ll}B_{1} & 15 \\
\text { days } & (\%)\end{array}$ & $\begin{array}{lr}B_{2} & 30 \\
\text { days } & (\%) \\
\end{array}$ & $\begin{array}{lr}B_{3} & 45 \\
\text { days }(\%)\end{array}$ & Mean \\
\hline $\begin{array}{l}\text { Retention of } 15 \mathrm{~cm} \text { fruiting } \\
\text { shoot length }+ \text { Thinning }\left(T_{1}\right)\end{array}$ & 8.00 & & 12.80 & 17.80 & 12.86 & 29.80 & 36.00 & 40.20 & 35.33 \\
\hline $\begin{array}{l}\text { Retention of } 30 \mathrm{~cm} \text { fruiting } \\
\text { shoot length }+ \text { Thinning }\left(\mathrm{T}_{2}\right)\end{array}$ & 12.00 & & 16.60 & 20.80 & 16.46 & 27.00 & 32.20 & 38.80 & 32.66 \\
\hline $\begin{array}{l}\text { Retention of } 45 \mathrm{~cm} \text { fruiting } \\
\text { shoot length }+ \text { Thinning }\left(T_{3}\right)\end{array}$ & 20.40 & & 24.80 & 30.00 & 25.06 & 18.80 & 28.40 & 32.60 & 26.60 \\
\hline $\begin{array}{l}\text { Retention of } 60 \mathrm{~cm} \text { fruiting } \\
\text { shoot length }+ \text { Thinning }\left(T_{4}\right)\end{array}$ & 25.80 & & 30.60 & 36.20 & 30.86 & 32.40 & 39.60 & 44.80 & 38.93 \\
\hline $\begin{array}{l}\text { (No head-back }+ \text { No thin- } \\
\text { ning }\left(T_{5}\right)\end{array}$ & 33.40 & & 37.80 & 42.80 & 38.00 & 38.40 & 44.40 & 51.00 & 44.60 \\
\hline Mean & 19.92 & & 24.52 & 29.52 & & 29.28 & 36.12 & 41.48 & \\
\hline $\mathrm{CD}_{0.05}$ & & & & & & & & \\
\hline Factors & & \multicolumn{2}{|c|}{$\mathrm{SE}(\mathrm{d})$} & \multicolumn{2}{|l|}{$\mathrm{SE}(\mathrm{m})$} & C.D. & $\mathrm{SE}(\mathrm{d})$ & \multicolumn{2}{|l|}{$\mathrm{SE}(\mathrm{m})$} \\
\hline Pruning & 0.79 & \multicolumn{2}{|c|}{0.39} & \multicolumn{2}{|l|}{0.27} & 0.76 & 0.38 & \multicolumn{2}{|l|}{0.27} \\
\hline Days interval & 0.61 & \multicolumn{2}{|c|}{0.30} & \multicolumn{2}{|l|}{0.21} & 0.59 & 0.29 & \multicolumn{2}{|l|}{0.20} \\
\hline Pruning $\mathrm{x}$ days Interval & NS & \multicolumn{2}{|c|}{0.68} & \multicolumn{2}{|l|}{0.48} & NS & 0.66 & 0.46 & \\
\hline
\end{tabular}

highest $(56.34 \mathrm{~cm})$. It also gave highest tree spread $(2.60 \mathrm{~m})$, tree height $(2.70 \mathrm{~m})$ and tree volume $(9.31$ $\left.\mathrm{m}^{3}\right)$, whereas minimum tree vigour was observed in case of $T_{1}$ in both years of study. The differences in the tree vigour may be attributed to the pruning treatment. The improved tree vigour of $\mathrm{T}_{5}$ may be due to no pruning, highest fruit set and more fruit drop as evident from the Table 1; as most of the metabolites were utilized for growth and vice-versa in case of $\mathrm{T}_{5}$. Maximum plant height $(2.70 \mathrm{~m})$ and shoot extension growth $(56.34 \mathrm{~cm})$ was recorded in $\mathrm{T}_{5}$ and $\mathrm{T}_{1}$. The minimum plant height $(1.52 \mathrm{~m})$ and extension shoot growth $(41.23 \mathrm{~cm})$ were observed in $T_{1}$ and $T_{4}$, respectively, which was probably due to the high productivity of this trait and vice-versa in case of $\mathrm{T}_{1}$ and $\mathrm{T}_{5}$ (Table2 ). These findings are in consistent with the previous reports (Masalkara et al., 2009 and Hassani and Rezeae, 2007) that the plant spread, plant height and tree volume are always higher in unpruned trees as compared to pruned ones.

Fruiting and yield: The unpruned trees had more number of fruits as compared to plants with pruning treatments. Final fruit retention at harvest is influenced by fruit abscission occurring during various stages of development. Retention of more fruiting shoots in terms of length and numbers along with higher fruit set might have favoured the more number of fruits in control. These findings are in consistent with the previous reports (Masalkara et al., 2009) that unpruned trees produced more fruits than pruned trees.

In these treatments, highest yield per plant $(10.25 \mathrm{~kg})$ and a number of fruits/tree (49.00) was recorded in $\mathrm{T}_{5}$ which was on par with $T_{1}, T_{2}, T_{3}$ and $T_{4}$ in terms of yield and number of fruits per plant (Table 2). The highest fruit setting $(54.73 \%)$ was recorded in $\mathrm{T}_{5}$, which was closely followed by $\mathrm{T}_{4}$ and $\mathrm{T}_{3}$. The highest fruit drop per cent $(12.11 \%)$ was recorded in $\mathrm{T}_{1}$ but on par with $\mathrm{T}_{5} \quad \mathrm{~T}_{4} \quad \mathrm{~T}_{3}$ and $\mathrm{T}_{2}$. The highest fruit size (Diameter and Length) 9.66 and 9.65 was recorded in Vitagliano $T_{1}$, which was closely followed by $T_{2}$ and $\mathrm{T}_{3}$. The highest fruit crack 2.5 was recorded in $\mathrm{T}_{1}$, which was closely followed by $\mathrm{T}_{2}$ and $\mathrm{T}_{5}$. The results are in accordance with the earlier findings that percent fruit set increased significantly with decrease in pruning severity (Gill and Bal, 2006) and reduction in total yield of fruits with the increase in pruning severity (Yang et al., 2009) heavy pruning registered the lowest fruit set in Sharbati, Flordasun and Prabhat cvs. of 
peaches (Kumar et al., 2005 and in apricot Sharma et al., 2017).

Fruit quality: The maximum fruit volume $\left(270.33 \mathrm{~cm}^{3}\right)$ and ascorbic acid content (15.95 $\mathrm{mg} / 100 \mathrm{~g}$ ) was observed for the treatment of $\mathrm{T}_{1}$. The minimum fruit length $(9.13 \mathrm{~mm})$ and fruit volume $\left(209.83 \mathrm{~cm}^{3}\right)$ were found in $\mathrm{T}_{5}$. Maximum TSS $(13.60$ ${ }^{0}$ Brix) and total sugar $(11.91 \%)$ was observ0065d in $\mathrm{T}_{1}$, whereas minimum TSS $\left(12.40{ }^{0} \mathrm{Brix}\right.$ and total sugar $(9.89 \%)$ was observed in $\mathrm{T}_{5}$ respectively (Table 3$)$. Maximum reducing sugars $(9.54 \%)$ and non- reducing sugar $(2.64 \%)$ were observed in $\mathrm{T}_{1}$, whereas minimum reducing sugar $(8.43 \%)$ and non-reducing sugar $(1.46 \%)$ was observed in $\mathrm{T}_{5}$ respectively (Table 3 ). The maximum titratable acidity $(0.56 \%)$ was observed in $\mathrm{T}_{5}$, whereas minimum $(0.32 \%)$ in $\mathrm{T}_{1}$. The maximum TSS: Acid ratio (42.10\%) was observed in $\mathrm{T}_{1}$, whereas minimum TSS: Acid ratio (21.86\%) was observed in $\mathrm{T}_{5}$ (Table 3 ). The results are in accordance with the earlier findings that percent TSS and other physicochemical characters increased significantly with severe pruning treatments (Hassani and Rezaee, 2007 and Sharma et al., 2017).

Disease incidence on fruit and leaf surface: The present investigation revealed that the disease incidence in the fruit and leaf surface were affected significantly by all the pruning treatments over control. Least disease incidence $(12.86 \%)$ on fruit surface was recorded in treatment $\mathrm{T}_{1}$ (retention of $15 \mathrm{~cm}$ fruiting shoot length) and on leaf surface $(26.60 \%)$ in $\mathrm{T}_{3}$ (retention of $45 \mathrm{~cm}$ fruiting shoot length) whereas high disease incidence both on fruit surface $(38.00 \%)$ and leaf surface $(44.60 \%)$ was recorded in treatment $\mathrm{T}_{5}$ (Table 4). However, the effect of pruning treatments on the durations were non-significant and maximum disease incidence was recorded in $\mathrm{T}_{5}$ (control). The results relating to the decrease in disease severity by different pruning treatments over control are in agreement with the findings of (Riedle, 2010) in grapes, (Lemus, 2010), in walnut (Yang, 2009) in persimmon and apricot Sharma et al. (2017).

\section{Conclusion}

The results obtained in the present investigation infer that different pruning treatments influenced growth and productivity of declining pomegranate trees. However among all the treatments $T_{1}$ recorded significantly highest tree growth $(56.34 \mathrm{~cm})$ and good quality fruits (Fruit size Diameter $9.66 \mathrm{~cm}$ and Length $9.65 \mathrm{~cm}$, Fruit Volume $270.33\left(\mathrm{~cm}^{3}\right)$, TSS $13.60{ }^{0}$ Brix, Total Sugars 11.91(\%), Reducing Sugars 9.45 (\%),TSS: Acid Ratio 42:10 and Disease severity on fruit surface $12.86 \%$ ) compere to all other treatments. The pruning treatment also proved to be beneficial in reducing the severity of diseases both on the fruits as well as leaves to some extent.

\section{ACKNOWLEDGEMENTS}

Authors are highly thankful for the facilities and funds provided by Dr. Yashwant Singh Parmar University of horticulture and forestry, Nauni, Solan 173230 (H.P.) India.

\section{REFERENCES}

Anonymous (2015). Indian Horticulture Database 2015, National Horticulture Board, Gurgaon.

AOAC. (1980). Official methods of analysis. Association of Official Analytical Chemists, 13th edition, W Horowitz (ed.) Benjamin Franklin Station, Washington, DC.101 p

Chandra, R., Babu K. D., Jadhav V. T., Jaime A. and Silva T. D. (2010). Origin, History and Domestication of Pomegranate. Fruit, Vegetable and Cereal Science and Biotechnology. 2: 1-6.

Du, T., Wang, P. C. and Francis, F. J. (1975). Anthocyanins of Pomegranate. J for sci., 40: 417-418.

Gill, K. S. and Bal, J. S. 2006. Influence of pruning severity and time on yield and fruit quality of ber cv. Umran., Department of Horticulture. PAU, Ludhiana.

Gomez, K. A. and Gomez, A. A. (1984). In: Statistical Procedure for Agricultural Research 2nd ed. New York: Willey Interscience. Pp. 304-309

Hassani, G. and Rezaee, R. (2007). Effect of training system and rate of pruning on yield and quality of peach fruit. Agriculture Science Tabriz, 17(1):31-38.

Hess, P. B. and Kades, A. A. (2003). Response of 'Wonderful' pomegranate to controlled atmosphere. Acta Hort, Proc. of 8th International conference.

Kaulgud, S. N. (2002). Pomegranate aril blackening: fungal or physiological disorder. In: Advances in arid and semi -arid fruit crops. Centre for Advanced Studies in Hort. (fruits). MPKV Rahuri. pp. 145-147.

Kumar, A., Pande, N. C. and Tripathi, V. K. (2005). Influence of pruning severity on the flowering and fruiting of peach. Farm Science Journal 14(1): 12-13.

Lemus, G. (2010). Innovative methods of walnut production in South America. Acta-Horticulture, 861: 191-198.

Masalkara, S. D., Joshi, V. R., Masalkar, S. D., Kulkarni, S. R. and Chavan, S. D. (2009). Effect of different pruning levels on yield and quality of pomegranate. 2nd International Symposium on "Pomegranate and Minor including Mediterranean Fruits", University of Argicultural Sciences, Dharwad, India.

Riedle, B. M., Hanak, K., Regner, F. and Tiefenbrunner. (2010). Influence of pruning measures on recovery of Bois noir-infected grapevines. Journal of Phytopathology, 158(9): 628-632.

Sharma, D. P. and Chauhan, J. S. (2004). Response of pruning intensities and fertilizer treatment on yield, fruit quality and photosynthetic efficiency of peach. Acta Horticulturae, 662: 237-241.

Sharma.,D. P. Chakma, J, Sharma, N. and Singh, N. (2017). Effect of different orchard management practices on the growth and production of rejuvenated of pomegranates (Punica granatum L.) cv. Kandhari Kabuli. Journal of Applied and Natural Science 9 (1): 577 - 581.

Stover, E. and Mercure E .W. (2007). The Pomegranate-a new look at the fruit of paradise. Hort Sci., 42(5): 1088-1097.

Vitagliano, C., Bartolini, S. and Catania, M. (2001). Summer 
D. P. Sharma and Niranjan Singh / J. Appl. \& Nat. Sci. 10(1): 358 - 362 (2018)

pruning increases sugar and starch content of peach flower buds, fruit retention and size. Acta Horticulturae, 565:93-98.

Warade, S. D., Joshi, V. R., Masalkar, S. D. and Kulkarni, S. R. (2009). Effect of different mulches on yield and quality of pomegranate. 2nd International Symposium on "Pomegranate and minor including mediterrenean fruits", University of Agricultural Sciences, Dharwad. P 104.

Yang, Y., Wang, R., Li, G. and Ruan, X. (2009). Observation of persimmon anthracnose in the national field genebank for persimmon. Acta Horticulture, 833: 109-112. 